\title{
The Effect Of Co-Op-Co-Op Learning Model Towards Students' Self Efficacy In Speaking Competence
}

\author{
Sri Ariani ${ }^{1}$, Eki Hendrawan ${ }^{2}$ \\ Program Studi Pendidikan Bahasa Inggris FBMB UNDIKMA \\ sri_ariani@ikipmataram.ac.id
}

\begin{abstract}
This research aims to determine the effect of co-op-co-op on students' self-efficacy in speaking to the second grade students of Al-Ashriyah Gunungsari. This research is preexperimental study with one group pretest-posttest design. The sample of this study consisted of 42 students; oral test is used as the instrument in this study. Pre-test and post-test are applied for one class. Data analysis techniques of this resaearch used descriptive statistics and inferential statistics. The findings of the study showed that the t-test was 111.7 and the t-table value was 1,684 with 40 degrees of freedom in the $0.05 \%$ confidence level. This shows that the alternative hypothesis ( $\mathrm{Ha})$ is accepted. It is revealed that the experimental average score is high. It concluded that the co-op-co-op method has significant effect in teaching speaking to second grade students of Al-Ashriyah Gunungsari. Based on the result of this research, it is reccomended for the teachers to apply co-op-co-op in teaching speaking for the students.
\end{abstract}

Key words: Co-op-co-op and self efficacy in speaking

\begin{abstract}
Abstrak: Penelitian ini bertujuan untuk mengetahui pengaruh Co-Op-Co-Op terhadap efikasi diri siswa dalam berbicara dalam bahasa Inggris pada siswa kelas II Al-Ashriyah Gunungsari. Penelitian ini merupakan penelitian pra eksperimental dengan rancangan one group pretest-posttest design. Sampel penelitian ini terdiri dari 42 siswa; Instrumen yang digunakan dalam penelitian ini adalah tes lisan. Teknik pengumpulan data dengan memberikan pre-test dan post-test untuk satu kelas. Teknik analisis data adalah statistik deskriptif dan statistik inferensial. Hasil penelitian menunjukkan nilai t-hitung 111,7 dan nilai t tabel 1,684 dengan tingkat kebebasan 40 pada taraf kepercayaan $0,05 \%$. Hal ini menunjukkan bahwa hipotesis alternatif (Ha) diterima dan karena nilai rata-rata eksperimen yang tinggi maka dapat disimpulkan bahwa metode Co-Op-Co-Op berpengaruh positif dalam pengajaran Speaking kepada siswa kelas dua Al-Ashriyah Gunungsari. Dari temuan penelitian ini, disarankan bagi guru untuk menggunakan Co-Op-Co-Op dalam Pengajaran Speaking.
\end{abstract}

Kata Kunci: Co-op-co-op and Efikasi diri dalam berbicara dalam bahasa Inggris

\section{INTRODUCTION}

Speaking is a person's way of conveying information, opinions or intentions. Speaking is quite difficult anymore we talk in front of many people such as in the context of discussion, seminars or in any context. Talking well is how a person can convey information to the others that involves the mind of the listener to understand and capture the points of the information we submit. Spratt (2003: 34) state that involves using speech to express meaning to other people Meanwhile, Brown (2003: 140) state that speaking as a productive skill that can be directly and empirically observed those observations are invariably colored by the accuracy effectiveness of a test-takers listening skill, which necessarily compromises the reliability and validity of an oral production test, the purpose of brown is the delivery of intention; opinion or information through oral can hear and see directly involving the hearing of others is common in seminars, discussions, speeches and others.

Based on the observation at SMP ALASHRIYAH there was a problem on students' self efficacy. The students were still 
lack confidence to convey their opinion and shy to speak in English in front other people in the classroom. When the teacher asked the students to speak in front of the class they did not have any courage and got nervous. Also when the teacher asked them to come forward they just silent. It happened because students still have low self efficacy. The method used by teachers seemed not suitable. Therefore the students become less active during teaching and learning process. To enhance students' self-efficacy the researchers applied CO-OPCO-OP. This strategy expected to overcome the students self efficacy in speaking. Co-OpCo-Op is usefull to increase students' confidence and speaking ability. It help them to interact with each other, help to improve students' speaking skills, build close relationships, and build student mentality.

Students' belief on their capability either positively or negatively influence their willingness to speak. For that reason, this study intentionally highlights students' belief on students' speaking skill in English, since one of the significant factors to control over students to speak english is their self-efficacy or what so called as belief (banura, 1977; Mahyudin, Elias, Cheong, Muhamas, noordin, \& Abdulah, 2006). In the other words, selfefficacy can be seen as the confidence that people have in their ability to do the thing that they try to do. If students have self efficacy then they will be motivated to succeed in achieving learning goals and can survive when facing difficulties. Schunk (2009) students who have self efficacy on learning, themselves tend to have more regularity (goal setting, use of active learning strategies, monitoring their understanding, evaluating the progress of their goals) and create an environment effective for learning (eliminating or minimizing distractions, finding effective learning partners).

Bandura (1997: 36) Self-efficacy theory acknowledges the diversity of human capabilities. Thus, it treats the efficacy belief system not as an omnibus trait but as a differentiated set of self-beliefs linked to distinct realms of functioning. self-efficacy theory is that the initiation of and persistence at behaviors and courses of action are determined primarily by judgments and expecta-tions concerning behavioral skills and capabilities and the likelihood of being able to successfully cope with environmental demands and challenges. Self-efficacy theory also maintains that these same factors play an important role in psychological adjustment and dysfunction and in effec-tive therapeutic interventions for emotional and behavioral problems.

In self-efficacy theory, beliefs about personal resources and abilities are the product of the interaction of information from six primary sources: a) performance or enactment experiences; (b) vicarious experiences; (c) imaginal experiences; (d) verbal persuasion; (e) physiological arousal; and (f) emotional states.

Self efficacy in each individual will differ from one individual to another based on three dimensions. Here are three dimensions, namely: Magnitude of self-efficacy, in a hierarchy of behaviors, refers to the number of "steps" of increasing difficulty or threat a person believes he capable of performing. For example, a person who is trying to abstain from smoking may believe that he can maintain abstinence under conditions in which he feels relaxed and in which no others present are smoking. He may doubt, however, his ability to abstain under conditions of higher stress and/or when in the presence of other smokers.

Strength of self-efficacy expectancy refers to the resoluteness of a person's convictions that he or she can perform a behavior in question. For example, two smokers may believe themselves capable of abstaining from smoking at a party, but one may hold this belief with more conviction or confidence than the other. Strength of selfefficacy expectancy has been related repeatedly to persistence in the face of frustration, pain, and other barriers to performance.

Generality of self-efficacy expectancies refers to the extent to which success or failure experiences influence selfefficacy expectancies in a limited, 
behaviorally specific manner, or whether changes in self-efficacy expectancy extend to other similar behaviors and contexts. For example, the smoker whose self-efficacy expectancy for absti-nence has been raised by successful abstinence in a difficult or highrisk situation (in a bar around other smokers) may extend his feelings of self-efficacy to other contexts in which he has not yet experienced success or mastery. In addition, successful abstinence might generalize to other contexts of self-control, such as eating or maintaining an exercise regimen.

Co-op-Co-op is a form of Group Investigation which is quite familiar. Method this puts the team in co-operation between one another to learn a topic in class. Robert E. Slavin (2005: 229) so co-op-co-op is a form of learning model that involves all students in a group which they will interact with each other so that will build relationships between students, do not feel ashamed to speak between them, So that the discussion will run well. Kagan (1985: 440) he essence of Co-op-co-op is to allow students to work together in small groups to advance their understanding of themselves and the world, and then to provide them with the opportunity to share that new understanding with their peers. The method is designed to be simple and flexible.

The essence of Co-op-Co-op is to allow students to work together in small groups to advance their understanding of themselves and the world, and then to provide them with the opportunity to share that new understanding with their peers, the method is designed to be simple and flexible. Once a teacher grasps the philosophy behind Co-op-Co-op, he ors he may choose any number of ways to operate the technique in a given classroom. Nevertheless, the inclusion of certain elements or steps increases the probability of success of the method.

\section{RESEARCH DESIGN}

The method used in this research is Pre-experimental design. The pre-experiment form that used is one-group pretest-posttest design in this design there is pretest, before the treatment is given, thus the results of the treatment can be known more accurately, because it can compare with the situation before being given treatment Sugiyono (2017: 110). To measure ability of student the researchers used questioner and speaking test to get score.

\section{TECHNIQUES OF DATA ANALYSIS}

After getting the data from the pre-test and posttest that has been carried out, the next process was analyzed or calculate the data by using statistical analysis as the researchers mentioned above, namely descriptive analysis and inferential statistics. Descriptive statistics used to determine the mean, mode, median and standard deviation, while inferential statistics to determine the conclusions of the research carried out is effective or not.

\section{RESEARCH FINDING DISCUSSION Finding}

Descriptive Statistic Data can be seen as follows:

Table 07

\begin{tabular}{|c|c|c|c|}
\hline \multicolumn{4}{|c|}{ Students' Score } \\
\hline No. & Students & Pre-test (X) & Post-test (Y) \\
\hline 1. & AR & 52 & 76 \\
\hline 2. & ADW & 52 & 72 \\
\hline 3. & AH & 60 & 72 \\
\hline 4. & AF & 52 & 72 \\
\hline 5. & AW & 60 & 68 \\
\hline 6. & BRN & 52 & 72 \\
\hline 7. & BRHU & 56 & 68 \\
\hline 8. & BZA & 56 & 68 \\
\hline 9. & DIQ & 68 & 80 \\
\hline 10. & DA & 56 & 76 \\
\hline 11. & EGR & 64 & 84 \\
\hline 12 & EH & 68 & 84 \\
\hline 13. & $\mathbf{H}$ & 68 & 84 \\
\hline 14. & HL & 64 & 72 \\
\hline 15. & IJ & 64 & 80 \\
\hline 16. & IZ & 60 & 76 \\
\hline 17. & I & 68 & 80 \\
\hline 18. & KA & 64 & 80 \\
\hline 19. & KT & 68 & 80 \\
\hline 20. & KK & 64 & 88 \\
\hline 21. & KH & 52 & 80 \\
\hline 22. & LARH & 64 & 76 \\
\hline 23. & LRS & 64 & 88 \\
\hline 24. & MFH & 64 & 76 \\
\hline 25. & MJI & 68 & 76 \\
\hline 26. & MHA & 56 & 80 \\
\hline 27. & MT & 56 & 88 \\
\hline 28. & MAU & 60 & 76 \\
\hline 29. & NS & 60 & 80 \\
\hline 30. & RR & 60 & 76 \\
\hline 31. & RA & 60 & 72 \\
\hline 32. & RA & 64 & 80 \\
\hline 33. & RR & 60 & 80 \\
\hline 34. & $\mathrm{~S}$ & 52 & 84 \\
\hline 35. & $\mathrm{ZS}$ & 60 & 72 \\
\hline 36. & AT & 64 & 80 \\
\hline 37. & SPA & 60 & 72 \\
\hline 38. & UW & 60 & 80 \\
\hline 39. & $\mathrm{Y}$ & 64 & 68 \\
\hline 40. & $\mathrm{ZS}$ & 60 & 76 \\
\hline 41. & $\mathrm{Z}$ & 60 & 72 \\
\hline 42. & $Z T$ & 52 & 76 \\
\hline
\end{tabular}


a) Frequency Distribution

$\mathrm{n}=42$

The highest (maximum) score $=88$, the lowest (minimum) score $=68$

Range $=$ Max-Min

$$
\begin{aligned}
& =88-68 \\
= & 20
\end{aligned}
$$

Number of class $=1+3.3 \log n$

$$
\begin{aligned}
& =1+3.3 \log 42 \\
& =1+3.3(1.623) \\
& =1+5.3 \\
& =6.3=7
\end{aligned}
$$

So, the number of the class can be 6 or 7 and the researcher took 7 as the number of the class.

$$
\begin{array}{ll}
\text { Interval (class } & \text { width) } \\
\text { mber of class } & =20 / 7 \\
& =2,85 \text { or } 3
\end{array}
$$

\begin{tabular}{|c|c|c|c|c|}
\hline $\begin{array}{l}\text { Class } \\
\text { limit }\end{array}$ & $\begin{array}{l}\text { Midpoint } \\
\left(\mathrm{x}_{\mathrm{i}}\right)\end{array}$ & Tally & $\begin{array}{c}\text { Frequency } \\
\left(\mathrm{f}_{\mathrm{i}}\right)\end{array}$ & $\mathrm{f}_{\mathrm{i}} \mathrm{X}_{\mathrm{i}}$ \\
\hline $68-70$ & 69 & IIII & 4 & 276 \\
\hline $71-73$ & 72 & IIITHIIII & 9 & 648 \\
\hline 74-76 & 75 & IIHA & 10 & 750 \\
\hline $77-79$ & 78 & & 0 & 0 \\
\hline $80-82$ & 81 & WIITHI & 12 & 972 \\
\hline $83-85$ & 84 & IIII & 4 & 336 \\
\hline $86-88$ & 87 & III & 3 & 261 \\
\hline & $\sum=546$ & & $\sum=42$ & $\sum=3243$ \\
\hline
\end{tabular}$$
\text { Range/Number of class } \quad=20 / 7
$$

Then, the frequency distribution of the data is shown in the table below:

Table 08:

\section{Frequency Distribution}

a) Calculated the Mean Score

$$
\begin{aligned}
M & =\frac{\sum f i \cdot X i}{\sum_{f i} i} \\
& =\frac{3243}{42} \\
& =77,2
\end{aligned}
$$

So, the mean score was 77.2

b) Calculated the Mode

$$
\begin{aligned}
\operatorname{Mode}(M o) & =b+p\left(\frac{b 1}{b 1+b 2}\right) \\
& =79.5+3\left(\frac{12}{12+8}\right)
\end{aligned}
$$

$$
\begin{aligned}
& =79.5+3(0.6) \\
& =79.5+(1.8) \\
& =81.3
\end{aligned}
$$

So, the mode was 81.3

c) Calculated the Median

$$
\begin{aligned}
& =76.5+3(0) \\
& =76.5
\end{aligned}
$$

So, the median was $76.5=77$

Table 09 Standard Deviation

\begin{tabular}{|c|c|c|c|c|c|}
\hline Score & xi & $\left(f_{i}\right)$ & $f_{i} x_{i}$ & $x^{2}$ & $f^{2} i^{2}$ \\
\hline $68-70$ & 69 & 4 & 276 & 4761 & 19044 \\
\hline $71-73$ & 72 & 9 & 648 & 5184 & 46656 \\
\hline $74-76$ & 75 & 10 & 750 & 5625 & 56250 \\
\hline $77-79$ & 78 & 0 & 0 & 6084 & 0 \\
\hline $80-82$ & 81 & 12 & 972 & 6561 & 78732 \\
\hline $83-85$ & 84 & 4 & 336 & 7056 & 28224 \\
\hline $86-88$ & 87 & 3 & 261 & 7569 & 22707 \\
\hline & & 42 & 3243 & & 251613 \\
\hline
\end{tabular}

d). Calculated the Standard Deviation

Before calculating the standard deviation value, first is to calculate the variance value.

- $\mathrm{S}^{2}=\frac{\sum f i x i^{2}-\frac{\left(\sum f i x i\right)^{2}}{\sum f i}}{\mathrm{n}-1}=$

$$
\begin{aligned}
& =\frac{251613-\frac{(3243)^{2}}{42}}{42-1} \\
& =\frac{251613-250405.9}{41} \\
& =\frac{1207.1}{41}=29.44 \\
S & =\sqrt{S^{2}} \\
& =\sqrt{29.44}=5.42
\end{aligned}
$$$$
\text { - } \mathrm{S}=\sqrt{S^{2}}
$$ 
2. Inferential Statistics

This kind of statistical analysis was used to make inference whether the alternative hypothesis accepted or not. First, the researcher calculated the value of t-test:

Table 10

T-test table

\begin{tabular}{|c|c|c|c|c|c|c|}
\hline \multirow[t]{2}{*}{ No. } & \multicolumn{3}{|c|}{ Pre-test } & \multicolumn{3}{|c|}{ Post-test } \\
\hline & (X1) & $\mathrm{x} 1$ & $x 1^{2}$ & (Y1) & $\mathrm{yl}$ & $y 1^{2}$ \\
\hline 1. & 52 & -8.38 & -70.22 & 76 & -1.14 & -1.299 \\
\hline 2. & 52 & -8.38 & -70.22 & 72 & -5.14 & -26.419 \\
\hline 3. & 60 & -0.38 & -0.144 & 72 & -5.14 & -26.419 \\
\hline 4. & 52 & -8.38 & -70.22 & 72 & -5.14 & -26.419 \\
\hline 5. & 60 & -0.38 & -0.144 & 68 & \begin{tabular}{|l|}
-9.14 \\
\end{tabular} & -83.539 \\
\hline 6. & 52 & -8.38 & -70.22 & 72 & -5.14 & -26.419 \\
\hline 7. & 56 & -4.38 & -19.18 & 68 & -9.14 & -83.539 \\
\hline 8. & 56 & -4.38 & -19.18 & 68 & -9.14 & -83.539 \\
\hline 9. & 68 & 7.62 & 58.06 & 80 & 2.86 & 8.179 \\
\hline 10. & 56 & -4.38 & -19.18 & 76 & -1.14 & -1.299 \\
\hline 11. & 64 & 3.62 & 13.10 & 84 & 6.86 & 47.059 \\
\hline 12 & 68 & 7.62 & 58.06 & 84 & 6.86 & 47.059 \\
\hline 13. & 68 & 7.62 & 58.06 & 84 & 6.86 & 47.059 \\
\hline 14. & 64 & 3.62 & 13.10 & 72 & $\begin{array}{l}-5.14 \\
\end{array}$ & -26.419 \\
\hline 15. & 64 & 3.62 & 13.10 & 80 & 2.86 & 8.179 \\
\hline 16. & 60 & -0.38 & -0.144 & 76 & -1.14 & -1.299 \\
\hline 17. & 68 & 7.62 & 58.06 & 80 & 2.86 & 8.179 \\
\hline 18. & 64 & 3.62 & 13.10 & 80 & 2.86 & 8.179 \\
\hline 19. & 68 & 7.62 & 58.06 & 80 & 2.86 & 8.179 \\
\hline 20. & 64 & 3.62 & 13.10 & 88 & 10.86 & 117.939 \\
\hline 21. & 52 & -8.38 & -70.22 & 80 & 2.86 & 8.179 \\
\hline 22. & 64 & 3.62 & 13.10 & 76 & -1.14 & -1.299 \\
\hline
\end{tabular}

a). Testing Hypothesis ( T-test )

$$
\begin{array}{r}
t=\frac{M x-M y}{\sqrt{\left(\frac{\sum x^{2}+\sum y^{2}}{N x+N y-2}\right)\left(\frac{1}{N x}+\frac{1}{N y}\right)}} \\
=\frac{60.38-77.14}{\sqrt{\left(\frac{-96.852+55.284}{42+42-2}\right)\left(\frac{1}{42}+\frac{1}{42}\right)}} \\
=\frac{-16.76}{\sqrt{\left(\frac{-41.56}{82}\right)(0.023+0.023)}} \\
=\frac{-16.76}{\sqrt{(-0.50)(0.046)}} \\
=\frac{-16.76}{\sqrt{0.023}} \\
=\frac{-16.76}{-0.15}=111.7
\end{array}
$$

The researcher found that $t_{0}=111.7$. Next, investigated the degree of freedom of the samples used the following formula:

$\mathrm{Df}=\mathrm{n}-\mathrm{k}$
$=(42-2)$

$$
\begin{gathered}
=40 \\
\text { Df }=40
\end{gathered}
$$

Found the value of $\mathrm{t}$-table $\left(\mathrm{t}_{\mathrm{t}}\right)$ using df (40) in confidence level of $0.05 \%$, that was 1.684. It means $t_{o}$ is higher than $t_{t}$, because $111.7>1.684$ it can be concluded that the alternative hypothesis was accepted.

\section{Table 11}

\section{Correlation table}

\begin{tabular}{|c|c|c|c|c|c|c|c|}
\hline No. & $\begin{array}{c}\text { Pre-test } \\
(\mathrm{X})\end{array}$ & $\begin{array}{c}\text { Post-test } \\
(\mathrm{Y})\end{array}$ & $\begin{array}{c}(x-\bar{x}) \\
\mathrm{x}\end{array}$ & $\begin{array}{c}(y \\
-\bar{y})\end{array}$ & $x^{2}$ & $y^{2}$ & $\mathrm{xy}$ \\
\hline 1. & 52 & 76 & -8.38 & -1.14 & -70.22 & -1.299 & 9.5532 \\
\hline 2. & 52 & 72 & -8.38 & -5.14 & -70.22 & -26.419 & 43.0732 \\
\hline 3. & 60 & 72 & -0.38 & -5.14 & -0.144 & -26.419 & 1.9532 \\
\hline 4. & 52 & 72 & -8.38 & -5.14 & -70.22 & -26.419 & 43.0732 \\
\hline 5. & 60 & 68 & -0.38 & -9.14 & -0.144 & -83.539 & 3.4732 \\
\hline 6. & 52 & 72 & -8.38 & -5.14 & -70.22 & -26.419 & 43.0732 \\
\hline 7. & 56 & 68 & -4.38 & -9.14 & -19.18 & -83.539 & 40.0332 \\
\hline 8. & 56 & 68 & -4.38 & -9.14 & -19.18 & -83.539 & 40.0332 \\
\hline 9. & 68 & 80 & 7.62 & 2.86 & 58.06 & 8.179 & 21.7932 \\
\hline 10. & 56 & 76 & -4.38 & -1.14 & -19.18 & -1.299 & 4.9932 \\
\hline 11. & 64 & 84 & 3.62 & 6.86 & 13.10 & 47.059 & 24.8332 \\
\hline 12 & 68 & 84 & 7.62 & 6.86 & 58.06 & 47.059 & 52.2732 \\
\hline 13. & 68 & 84 & 7.62 & 6.86 & 58.06 & 47.059 & 52.2732 \\
\hline 14. & 64 & 72 & 3.62 & -5.14 & 13.10 & -26.419 & -18.6068 \\
\hline 15. & 64 & 80 & 3.62 & 2.86 & 13.10 & 8.179 & 10.3532 \\
\hline 16. & 60 & 76 & -0.38 & -1.14 & -0.144 & -1.299 & 0.4332 \\
\hline 17. & 68 & 80 & 7.62 & 2.86 & 58.06 & 8.179 & 21.7932 \\
\hline 18. & 64 & 80 & 3.62 & 2.86 & 13.10 & 8.179 & 10.3532 \\
\hline 19. & 68 & 80 & 7.62 & 2.86 & 58.06 & 8.179 & 21.7932 \\
\hline 20. & 64 & 88 & 3.62 & 10.86 & 13.10 & 117.939 & 39.3132 \\
\hline 21. & 52 & 80 & -8.38 & 2.86 & -70.22 & 8.179 & -23.9668 \\
\hline
\end{tabular}

b). Correlation

$$
\begin{aligned}
r_{x y} & =\frac{\sum x y}{\sqrt{\sum x^{2} y^{2}}} \\
= & \frac{349.7144}{\sqrt{96.852+55.284}} \\
= & \frac{349.7144}{\sqrt{152.136}} \\
= & \frac{349.7144}{12.33} \\
= & 28,362
\end{aligned}
$$

Found the value of r-table $\left(\mathrm{r}_{\mathrm{t}}\right)$ using df (40) in confidence level of $0.05 \%$, that was 0.312 . It means $r_{o}$ is higher than $r_{t}$, because 28.362 $>0.312$ it can be concluded that there is 
correlation between self efficacy and speaking competence.

Table 12

Questionnaire

\begin{tabular}{|c|c|c|c|c|c|c|c|}
\hline No. & Students & SS & $\mathrm{S}$ & $\mathrm{N}$ & TS & STS & total \\
\hline & Score & $\times 5$ & $\mathrm{x} 4$ & $\mathrm{x} 3$ & $\mathrm{x} 2$ & $\mathrm{x} 1$ & \\
\hline 1. & AR & 6 & 4 & 3 & 5 & 2 & 67 \\
\hline 2. & ADW & 5 & 6 & 3 & 3 & 3 & 67 \\
\hline 3. & $\mathrm{AH}$ & 12 & 3 & 2 & 2 & 1 & 83 \\
\hline 4. & $\mathrm{AF}$ & 10 & 3 & 3 & 3 & 1 & 78 \\
\hline 5. & AW & 8 & 4 & 3 & 3 & 2 & 73 \\
\hline 6. & BRN & 9 & 3 & 3 & 3 & 2 & 74 \\
\hline 7. & BRHU & 13 & 4 & 2 & 1 & 0 & 89 \\
\hline 8. & BZA & 12 & 4 & 2 & 2 & 0 & 86 \\
\hline 9. & DIQ & 11 & 3 & 3 & 2 & 1 & 79 \\
\hline 10. & DA & 10 & 5 & 2 & 2 & 1 & 81 \\
\hline 11. & EGR & 9 & 4 & 3 & 2 & 2 & 76 \\
\hline 12 & EH & 12 & 3 & 3 & 2 & 0 & 85 \\
\hline 13. & $\mathrm{H}$ & 10 & 4 & 4 & 2 & 0 & 82 \\
\hline 14. & HL & 12 & 4 & 2 & 2 & 0 & 86 \\
\hline 15. & 10 & 9 & 6 & 2 & 2 & 1 & 77 \\
\hline 16. & IZ & 12 & 4 & 2 & 2 & 0 & 86 \\
\hline 17. & I & 14 & 2 & 2 & 2 & 0 & 88 \\
\hline 18. & KA & 13 & 4 & 2 & 1 & 0 & 89 \\
\hline 19. & KT & 10 & 5 & 3 & 1 & 1 & 82 \\
\hline 20. & KK & 11 & 4 & 2 & 2 & 1 & 82 \\
\hline 21 . & KH & 9 & 5 & 3 & 2 & 1 & 79 \\
\hline 22. & LARH & 12 & 4 & 2 & 1 & 1 & 85 \\
\hline
\end{tabular}

c). Questionnaire of self efficacy

In this case to know is there increasing students' self efficacy or not, to find out the result researcher counted student score of questionnaire with formula:

$\mathrm{FS}=\frac{\text { Total Score }}{\text { highest score } x \text { student number }} X 100$

$=\frac{3369}{89 \times 42} \times 100$

$=\frac{336900}{3739}$

$=90.1(90)$

Table 13

Self Efficacy Criteria Level

\begin{tabular}{|c|c|}
\hline interval & Criteria \\
\hline $91-100$ & Very high \\
\hline $78-90$ & High \\
\hline $65-77$ & High enough \\
\hline $52-64$ & Medium \\
\hline $39-51$ & Low enough \\
\hline $26-38$ & Low \\
\hline $14-25$ & Very low \\
\hline
\end{tabular}

Sadewi (2012)
The final score of questionnaire was 90; based on Self Efficacy Criteria Level table students' self efficacy.

Researchers implemented the co-op-coop method in teaching and learning process. At the first and second meetings, the pre-test conducted by examining students or taking grades by the absence of treatment or the lack of application of the co-op-co-op method itself, to find out how far the students have knowledge. Then the third to the seventh student meeting taught by applying the co-opco-op method or treatment. After that the last meeting held posttest to test the students or to take grades to find out whether there is an increase or not and also to compare before or after the treatment of students.

Student scores analyzed using statistical analysis, namely descriptive statistics and inferential statistics. Statistical descriptive analysis used to provide information on student values such as mean, mode, median and standard deviation. While inferential statistical analysis used to provide information on the value of the sum of testing hypotheses and correlations. With this statistical analysis, the researcher calculate the of student score.

After getting the data from the pre-test and posttest that has been carried out, the next process was analyzed and calculated the data by using statistical analysis namely descriptive analysis and inferential statistics. Descriptive statistics used to determine the mean, mode, median and standard deviation, while inferential statistics to determine the conclusions of the research carried out is effective or not.

Before calculating the standard deviation value, first is to calculate the variance value. This kind of statistical analysis was used to make inference whether the alternative hypothesis accepted or not. First, the researchers calculated the value of t-test. The researchers found that to $=111.7$. Next, investigated the degree of freedom. It is found the value of t-table (tt) using df (40) in confidence level of $0.05 \%$, that was 1.684 . It means to is higher than $\mathrm{tt}$, because 111.7 
$>1.684$ it can be concluded that the alternative hypothesis was accepted.

It is found the value of r-table $\left(r_{t}\right)$ using $\mathrm{df}$ (40) in confidence level of $0.05 \%$, that was 0.312. It means $r_{o}$ is higher than $r_{t}$, because $28.362>0.312$ it can be concluded that there is correlation between self efficacy and speaking competence.

To find out whether there is any increment of students' self efficacy or not, researcher counted students questionnaire score. It found that students questionnaire score 90. Based on Self Efficacy Criteria Level table students' self efficacy at SMP AL-ASHRIYAH was high.

\section{DISCUSSION}

There are two statement of problems of this research such as: Is there any effect of coop- co-op learning model towards students' self- efficacy in speaking competence. Also, Is there any correlation between Self-Efficacy and speaking competence.

English as the foreign language becomes one of the compulsory subjects in junior High School in Indonesia. One of the language skills that must be mastered by foreign language learners is speaking or communicating orally using target language. However, the fact has known that it is quite difficult for Indonesian learners to improve their speaking ability because they usually prefer to use their native language in their daily life than using English There are many factors that speaking is difficult according to the teacher and students. Some of them are related to the students' limited encounter with English spoken language and opportunities in practice speaking orally. Each student also needs to share and exchange the information to others. It gives them a reason to communicate with others by speaking English.

Co op cop method encourages students' self-efficacy. In this method, students strive to appreciate not only their own self but also other students as he speaks English. Every member in the group is so important that the students have to respect one other. Discussions among students also help them improve their confidence. Because student's complete assignments in groups, they can do it help each other through discussion. The respect of their student friends as they are Discuss with others can increase their self-efficacy' Therefore co-opco-op method is very helpful in building students' self-efficacy and encouraging than to speak because in co op co op method they are always discussing and it is practicing their speaking skills so that ova time they will get used to talking. Statement of problems of this research: Is there any effect of co-op- co-op learning model towards students' selfefficacy in speaking competence. Also Is there any correlation between Self-Efficacy and speaking competence.

The researchers used descriptive statistic and inferential statistic to calculate all of data.Mean is a group explanation technique based on the average value of the group. The mean (average) is obtained by summing the data of all individuals in the group, and then divided by the number of individuals in the group (Sugiyono, 2017: 49). To calculate the data mode that has been compiled into the distribution of frequency / data classified (Sugiyono, 2017: 52).

Median is one group explanation technique based on the mean value of the data set that has been arranged from the smallest to the largest or vice versa from the largest to the smallest (Sugiyono, 2017: 53).

One statistical technique used to describe the homogeneity of a group is by the number of squares of all deviations of individual value values against the group average, to find out the value of standard deviation (Sugiyono, 2017: 58) Inferential Statistics

The part of statistic to analyze sample data to make conclusion about a population, to find out the value of t-test (Suharsimi, 2010: 311 in Imran, 2015: 21).

To know there is effect of co-op-co-op learning model towards students' self efficacy in speaking competence. The researchers compare the result of t-test to t-table. If the result of or t-test $>\mathrm{t}$-table, the alternative 
hypothesis is accepted but if the result of $t-$ test $<\mathrm{t}$-table then the null hypothesis is rejected. Correlation product moment is used to find out relation and to prove hypothesis two variables, Correlation is use to find out significant whether self efficacy and speaking competence have any correlation (Sugiyono, 2017: 228). To know students' self efficacy the researchers gave questionnaire to students.

Based on these findings, the researcheress concluded that the co-op-co-op method had positive effect on teaching speaking at the second grades of Al-Ashriyah Gunungsari. The result showed that the value of the t-table in $0.05 \%$ significance level. It can be concluded that the alternative hypothesis (Ha) is accepted.

Based on the research when researchers came to class for the first time, researchers found that most students were still confused, especially to speak in front of the class. Most of them were confused about how to start their conversation, arranging words to express their opinion. The Co-Op-Co-Op method is used to treat experimental classes. The researchers gave an overview to students. Then, ask students to tell about the title given. The teacher asks several students to progress according to each group that has been formed, to tell or describe based on the title then the researchers discussed it with the whole class or evaluated how well students understand the materials delivered. For this reason, the alternative hypothesis $(\mathrm{Ha})$ is accepted, which means that the Co-Op-Co-Op method has a positive effect in teaching speaking.

\section{CONCLUSION}

According to the results of the analysis, the t_o value is 111.7 and the $t$ t $t$ value of $\mathrm{df}$ (40) at the $0.05 \%$ significance level is 1,684 , it can be concluded that the t_o value is higher than the $\mathrm{t} \_\mathrm{t}$ value, so that means that there is a significant difference between the scores before the treatment and after the treatment with co-op-co-op method. So, the alternative hypothesis (Ha) is accepted and the null hypothesis (Ho) is rejected. The coop-co-op method has a positive effect on teaching speaking, because it made students more easily to tell story, describe and good conversations in front of the class.

\section{SUGGESTION}

As a facilitator and motivator, an English teacher should be able to use good and appropriate techniques in teaching, especially in teaching Speaking English. Because it is a foreign language, it is possible that some students will be bored and confused if the teacher only comes to speak without knowing the condition of the student. Whether students understand or not, interesting or not, etc. Researchers suggest that teachers can use various techniques in different materials. Especially in teaching speaking, teachers can use the co-op-co-op method in teaching. Researchers hope that students become active and creative participants in the classroom. They must be active, and use critical thinking. Don't just come, sit and listen. Don't be afraid to ask if something is confusing or unclear in their minds.

\section{BIBLIOGRAPHY}

Adrian Dinata Dwi Dharma. Students' SelfEfficacy: A Case Study on The First Semester Student English Education at Jambi University. https://repository.unja.ac.id/4403/1/a rtikel.pdf

Bandura. A. 1997. Self Efficacy the Exercise of Control. New York. W. H. Freeman and Company.

Brown. H.D. 2003. Language Assessment Principles and classroom practice, San Francisco: Longman.

Brown. H.D. 2003. Language Assessment Principles and classroom practice, San Francisco: Longman.

Fathurrahman Imran. 2015. Penelitian Experiment. IKIP Mataram. Unpublished.

Gede A.S.W., Nym. Santiyadnya, Made S.G. 2015. penerapan model pembelajaran kooperatif tipe co-op co-op untuk meningkatkan hasil belajar keterampilan kelistrikan pada siswa kelas ix Al smp negeri 6 
singaraja tahun ajaran 2014/2015.

Indonesia. E-journal Jurnal JPTE Universitas Pendidikan Genesha.

Maddux. J.E. 1995. Self Efficacy, Adaptation, and Adjustment Theory, Research, and Application. New York: Plenum Press.

Maryuliana, Imam Much Ibnu Subroto, Sam Farisa Chairul Haviana. 2017. Sistem Informasi Angket Pengukuran Skala Kebutuhan Materi Pembelajaran Tambahan Sebagai Pendukung Pengambilan Keputusan Di Sekolah Menengah Atas Menggunakan Skala Likert. Indonesia . Universitas Islam Sultan Agung

Robert S., Shlomo S., Spencer K., Rachel H.L., Clark W. \& Richard S. 1985. Learning to Cooperate, Cooperating to Learn .New York: Plenum Press.

Spratt. M. 2003. The TKT Teaching Knowledge Test Course. Cambridge University: Press.

Sugiyono. 2017. .Statistika Untuk Penelitian. Bandung: Alpabeta.

Sugiyono. 2017. Metode penelitian pendidikan. Bandung: Alpabeta.

Yoni Sunaryo. 2017. Pengukuran selfefficacy siswa dalam pembelajaran matematika di mts $n 2$ ciamis. Indonesia. Universitas Galuh Ciamis. 